10. Herneho, Yu. O., Herneho, Yu. A. Investytsiina pryroda venchurnoi filantropii: sutnisni kharakterystyky ta maibutnie. Materialy I Mizhnarodnoi naukovo-praktychnoi konferentsii "Modernizatsiia ekonomiky: suchasni realii, prohnozni stsenarii ta perspektyvy rozvytku", Kherson, 2019, Available at: https://ir.kneu.edu.ua/bitstream/handle/123456789/32578/Ger_19_4_3.pdf?sequence=1. [in Ukrainian].

11. Khomenko H. Yu. Rozvytok venchurnoi filantropii v umovakh hibrydnoi viiny napriamy vdoskonalennia oblikovoho zabezpechennia. Problemy teorii ta metodolohii bukhhalterskoho obliku, kontroliu i analizu. 2019, Vol. 3 (44). Available at: http://pbo.ztu.edu.ua/article/view/195582/195972. [in Ukrainian].

12. Zanina, A. A. Venchurnaia fylantropyia: sushchnost y osnovnye pryntsypy funktsyonyrovanyia. Visnyk studentskoho naukovoho tovarystva DonNU imeni Vasylia Stusa, 2014, Vol. 2 (6), pp. 113-118. [in Russian].

13. Krashchym buty. Blahodiinyi fond. Official site. Available at: http://bestbe.cv.ua.

14. Spilnokosht. Official site. Available at: https://biggggidea.com.

15. Na-starte. Official site. Available at: https://web.archive.org/web/20170807215330/http://na-starte.com/about.

16. GoFundEd. Official site. Available at: https://gof.org.ua.

17. StartWay. Official site. Available at: https://start-way.com.ua/uk.

18. Tkachuk I. Ya. Finansove zabezpechennia diialnosti hromadskykh orhanizatsii Ukrainy: naukova monohrafiia. Chernivtsi. Tekhnodruk, 2016. 272 p. [in Ukrainian].

19. Tkachuk I. Ya. Kraudfandynh v konteksti zaluchennia dodatkovykh resursiv dlia realizatsii proektiv derzhavno-pryvatnoho partnerstva. Innovatsiina ekonomika, 2016., Vol. 5-6, pp. 183-186. [in Ukrainian].

Дата подання публікації 02.09.2020 р.

УДК 339.92

Туролєв Г. О., аспірант

Turolyev G. O., post graduate student ДВНЗ «Київський національний економічний університет імені Вадима

Гетьмана»

https://orcid.org/0000-0001-5579-0626

\title{
ГЛОБАЛІЗАЦІЙНІ ТЕНДЕНЦІї РОЗВИТКУ ОФШОРНОГО БАНКІНГУ
}

\author{
ДВНЗ «Київський національний економічний університет імені Вадима Гетьмана»
}

Глобальні умови функціонування світової банківської системи закладають якісно нові умови акумулювання і перерозподілу фінансового капіталу за різними регіонами і секторами світової економіки, а також трансформації сукупних заощаджень економічних агентів різних країн у глобальний інвестиційний капітал. Особливе місце у світовій банківській архітектурі посідає офшорне банківництво, яке в останні десятиліття перетворилось на усталений й невід'ємний компонент глобального фінансового ринку. Охоплюючи операції банківських установ, що локалізовані в офшорних юрисдикціях, офшорний банкінг забезпечує підприємницьким структурам значне послаблення податкового навантаження, високу конфіденційність комерційних угод та надійне збереження капіталу. У той самий час поглиблення міжнародної спеціалізації і виробничого кооперування, фрагментація глобальних потоків товарів i капітальних ресурсів забезпечують економічним суб'єктам широкі можливості щодо застосування послуг офшорного банківського бізнесу у цілях використання особливих систем корпоративного законодавства.

У статті розкрито масштаби і структурну динаміку офшорного банківництва в останні десятиліття. Комплексно охарактеризовано сучасні тенденції розвитку офшорних банків 3 акцентуванням дослідницького інтересу на процесах системної технологізації і динамічному поширенні фінтеху і штучного інтелекту, проникнення у даний сектор технологій електронної комерції, його переведення на технології блокчейну, посилення клієнт-орієнтованості і персоніфікованості офшорних банківських операцій, глибокої конвергенції діяльності офшорних банків й міжнародних інвестиційних компаній, активізації злиттів трастових офшорних компаній та ін. Доведено, що дані тенденції відбивають глобальний характер діяльності офшорних банків, високий рівень інноваційності їх сервісів, неухильну диверсифікацію банківських послуг та підвищення рівня стійкості банківської системи до дії чинників світової економічної нерівноваги. Особливу увагу приділено питанню щодо реалізації блокчейн-стартапів та організації бірж 3 торгівлі цифровими валютами, що справляють вагомий вплив на механізми функціонування офшорного банківництва. Обгрунтовано, що клієнтам офшорних банків надається на сьогодні широкий спектр послуг, що виходить далеко за рамки власне банківського обслуговування, й 
охоплює також консалтингові сервіси з питань податкового законодавства, оптимізації податкових витрат, заснування офшорного бізнесу тощо.

Ключові слова: офиорне банківництво, фінтех, штучний інтелект, електронна комерція, блокчейн.

\title{
GLOBALIZATION TRENDS OF OFFSHORE BANKING DEVELOPMENT
}

\author{
SHEI «Kyiv national economic university named after Vadym Hetman»
}

\begin{abstract}
Global conditions for the functioning of the world banking system lay qualitatively new conditions for the accumulation and redistribution of financial capital in different regions and sectors of the world economy, as well as the transformation of aggregate savings of economic agents of different countries into global investment capital. A special disposition in the global banking architecture is occupied by offshore banking, which in recent decades has become an established and integral component of the global financial market. Covering the operations of banking institutions, located in offshore jurisdictions, offshore banking provides businesses with a significant reduction in the tax burden, high confidentiality of commercial transactions and reliable preservation of capital. At the same time, the deepening of international specialization and industrial cooperation, the fragmentation of global flows of goods and capital resources provide economic entities with ample opportunities to use the services of offshore banking in order to use special systems of corporate law.

The article reveals the scale and structural dynamics of offshore banking in recent decades. The modern tendencies of development of offshore banks have been characterized with emphasis of research interest on processes of system technologization and dynamic distribution of fintech and artificial intelligence, penetration into this sector of technologies of e-commerce, its transfer to blockchain technologies, strengthening of clientorientation and personification of offshore operations, intensification of mergers of trust offshore companies, etc. It is proved that these trends reflect the global nature of offshore banks, the high level of innovation of their services, the steady diversification of banking services and increasing the level of resilience of the banking system to the factors of global economic imbalance. Particular attention is paid to the implementation of blockchain startups and the organization of exchanges for digital currency trading, which have a significant impact on the mechanisms of offshore banking. It is substantiated that the clients of offshore banks are currently provided with a wide range of services, which goes far beyond the actual banking services, and also includes consulting services on tax legislation, tax cost optimization, establishing an offshore business and more.
\end{abstract}

Key words: offshore banking, fintech, artificial intelligence, e-commerce, blockchain.

Постановка проблеми у загальному вигляді i iï зв'язок 3 важливими науковими та практичними завданнями. Одним 3 домінуючих глобальних трендів розвитку міжнародного бізнесу у першій чверті XXI ст. є системні процеси його офшоризації. Бізнес-офшоринг у своєму загальному інституційному форматі спрямований на нарощування міжнародними компаніями конкурентних переваг на основі інтерналізації фінансово-господарських операцій, реструктуризації корпоративних управлінських систем, реалізації механізмів податкової оптимізації і «розмивання» податкової бази. Як свідчить світовий досвід, у глобальній банківській архітектурі особливе місце посідає офшорне банківництво, яке в останні десятиліття перетворилось на усталений сегмент світового фінансового ринку. Воно включає операції банківських установ, що локалізовані в офшорних юрисдикціях, тобто регіонах i спеціалізованих зонах з особливими системами корпоративного законодавства i прибуткового оподаткування підприємницьких і бізнес-структур, що забезпечують компаніям значне послаблення податкового навантаження, високу конфіденційність комерційних угод та надійне збереження капіталу.

Аналіз останніх досліджень, у яких започатковано вирішення проблеми. Комплексні дослідження проблематики транснаціоналізації бізнесу, діяльності міжнародних фінансових центрів, внутрішньої і зовнішньої офшоризації економічної діяльності та тенденцій iї розвитку, корпоративних стратегій бізнес-офшорингу і механізмів їх реалізації містять наукові праці вітчизняних і зарубіжних вчених. Серед них, зокрема, А. Березной [8]; Л. Вевеге [7]; О. Власюк [9]; Дж. Гарсіа-Бернандо, Дж. Фітчер, Ф. Тейкс і Е. Хімскерк [3]; Т. Желюк [10]; І. Красавін [12]; Ф. Лейн і М. МілесіФерретті [4]; Б. Логінов, Є. Смірнов і А. Михайлін [15]; I. Макарова [13]; А. Матусевич 
[14]; О. Пузакова і Т. Шепель [17]; А. Ужгінцев [20] та багато інших. Разом з тим, незважаючи на велику кількість публікацій у даній царині, проблематика бізнесофшорингу дотепер залишається ще далеко не вичерпаною, що обумовлює високу актуальність комплексних досліджень офшорного банківництва та глобалізаційних тенденцій його розвитку.

Цілі статті. Метою статті є комплексний аналіз масштабів, структурної динаміки та тенденцій розвитку офшорного банківництва у глобальних умовах, що детермінують його фундаментальний вплив на процеси транскордонного руху фінансового капіталу.

Виклад основного матеріалу дослідження 3 повним обгрунтуванням отриманих наукових результатів. Світова система офшорного банківництва, зародившись у другій половині 1960 -х років після впровадження Банком Англії дворівневої банківської системи для Багамських островів [11, с. 74], згодом поширилась на інші світові регіони, сформувавши на початку XXI ст. загальнопланетарну банківську мережу. Підтвердженням високої динаміки його розвитку є дані, наведені у табл. 1, які свідчать про те, що упродовж 1977-2020 рр. сукупні активи офшорного банківського сектору зросли з 95,2 млрд до майже 5,3 трлн дол. США; а сукупні зобов' язання - 3 71,2 млрд до 4,8 трлн відповідно. При цьому спостерігається неухильне збільшення частки офшорних центрів у загальних активах і пасивах світової банківської системи з 13,8\% у 1977 р. до 15,9\% у 2020 р. та 3 10,7\% до 16,3\% відповідно ${ }^{1}$. Це свідчить про випереджальне зростання зобов'язань офшорних банків (порівняно 3 їх активами) у глобальній системі банківських послуг у формі вимог до їх активів - коштів на поточних клієнтських рахунках, кредиторської заборгованості, заборгованості за нарахованими процентами та відстроченої дебіторської заборгованості за доходами, за виключенням доходів, прибутку та внутрішньобанківських розрахунків.

Маємо також зазначити збереження у довгостроковому періоді тенденції щодо прискореного нагромадження активів і зобов'язань банків розвинутих країн світу. Їх частка становить нині 70,1\% загальносвітових активів банківської системи (у тому числі $25,8 \%$ - єврозони) і 64,7\% сукупних банківських зобов'язань (24,8\% відповідно). Для порівняння: у 1977 р. аналогічні показники становили 57,1\% (27,8\% по єврозоні) та $64,9 \%(24,1 \% \text { відповідно })^{2}$.

Таблиця 1

Ключові показники функціонування глобальної системи офшорного банківництва у

1977-2020 рр., на кінець року, млрд дол. США [6]

\begin{tabular}{|c|c|c|c|c|c|c|c|c|c|c|}
\hline \multirow{2}{*}{ Показник } & \multirow[b]{2}{*}{ : } & \multirow[b]{2}{*}{ 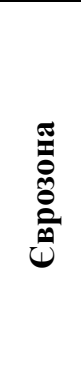 } & \multirow[b]{2}{*}{ 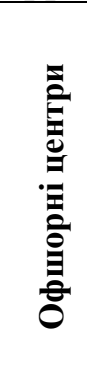 } & \multicolumn{4}{|c|}{ Країни, що розвиваються } & \multirow[b]{2}{*}{ 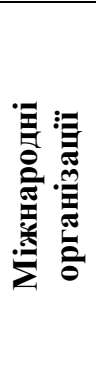 } & \multirow[b]{2}{*}{$\stackrel{\text { 䍖 }}{ }$} & \multirow[b]{2}{*}{$\begin{array}{l}0 \\
\dot{0} \\
\stackrel{0}{0} \\
\lambda\end{array}$} \\
\hline & & & & 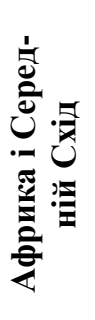 & 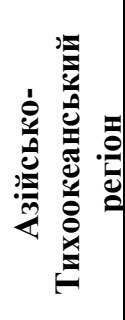 & 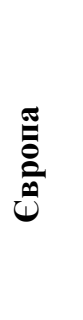 & 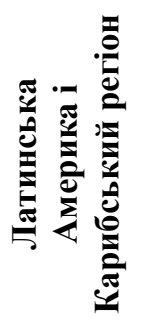 & & & \\
\hline \multicolumn{10}{|c|}{1977} & \\
\hline Активи & 393,0 & 190,9 & 95,2 & 47,0 & 24,5 & 45,0 & 79,4 & 3,6 & 0,0 & 687,8 \\
\hline Зобов'язання & 430,8 & 159,6 & 71,2 & 76,5 & 23,7 & 15,5 & 38,2 & 7,1 & 0,0 & 663,0 \\
\hline \multicolumn{10}{|c|}{1983} & \\
\hline Активи & 1194,1 & 459,6 & 343,6 & 124,7 & 93,9 & 68,0 & 243,4 & 15,5 & 0,6 & 2083,8 \\
\hline Зобов'язання & 1301,0 & 330,4 & 355,2 & 155,5 & 67,2 & 26,5 & 77,3 & 12,9 & 0,1 & 1995,7 \\
\hline
\end{tabular}

\footnotetext{
${ }^{1}$ Примітка.

Розраховано автором за даними табл. 1.

2 Примітка.

Розраховано автором за даними табл. 1.
} 


\begin{tabular}{|c|c|c|c|c|c|c|c|c|c|c|}
\hline Активи & 4407,5 & 1427,2 & 1053,5 & 152,1 & 175,8 & 117,9 & 210,5 & 47,0 & 14,1 & $\mathbf{6 1 7 8 , 4}$ \\
\hline Зобов'язання & 4404,3 & 1508,7 & 1046,9 & 289,0 & 185,7 & 41,0 & 146,1 & 35,7 & 0,0 & $\mathbf{6 1 4 8 , 7}$ \\
\hline \multicolumn{8}{|c|}{2000} \\
\hline Активи & 8367,1 & 3310,1 & 1240,9 & 169,0 & 283,0 & 146,4 & 287,8 & 54,9 & 0,9 & $\mathbf{1 0 5 4 9 , 9}$ \\
\hline Зобов'язання & 6578,7 & 2059,1 & 1670,6 & 321,8 & 348,7 & 94,8 & 247,2 & 96,2 & 139,3 & $\mathbf{9 4 9 7 , 3}$ \\
\hline \multicolumn{8}{|c|}{2007} \\
\hline Активи & 26332,5 & 11567,6 & 4067,6 & 459,3 & 829,7 & 728,0 & 402,5 & 88,8 & 0,4 & $\mathbf{3 2 9 0 8 , 8}$ \\
\hline Зобов'язання & 20565,9 & 7864,6 & 5190,2 & 873,7 & 859,0 & 458,3 & 383,4 & 243,9 & 495,9 & $\mathbf{2 9 0 7 0 , 1}$ \\
\hline \multicolumn{8}{|c|}{2010} \\
\hline Активи & 22900,4 & 9668,0 & 3916,1 & 499,2 & 1064,2 & 710,9 & 532,7 & 133,8 & 0,3 & $\mathbf{2 9 7 5 7 , 5}$ \\
\hline Зобов'язання & 18741,7 & 6680,0 & 4505,3 & 740,9 & 724,6 & 286,8 & 424,3 & 214,5 & 528,2 & $\mathbf{2 6 1 6 6 , 3}$ \\
\hline
\end{tabular}

Зазначені показники відбивають концентрацію у державах-лідерах глобального офшорного багатства, яке тільки у період 2003-2016 pp. збільшилось 3 3,9 до майже 8 трлн дол. США [2, с. 10]. 3 них на кінець періоду 5,9 трлн дол. становили емітовані в офшорних зонах цінні папери і 2 трлн дол. - депозити в офшорних банках. При цьому офшорне багатство жителів СС оцінюється на кінець періоду у 1,6 трлн дол. США, або у середньорічному обчисленні 1,5 трлн дол. упродовж 2001-2016 рр. [2, с. 10]. Даний факт підтверджує домінування держав-лідерів у розбудові глобальної системи офшорного банківництва, які з метою його використання у цілях здобуття податкових «притулків» для свого капіталу динамічно розвивають і модернізують офшорний інструментарій банківського обслуговування фінансово-господарських операцій своїх економічних суб'єктів [21, с. 37].

Офшорне банківництво у сучасних умовах характеризується низкою узагальнюючих тенденцій, що засвідчують його глобальний характер, високий рівень інноваційності, неухильну диверсифікацію банківських послуг та підвищення рівня стійкості банківської системи. Насамперед слід відзначити його системну технологізацію й динамічне поширення фінтеху (англ. - FinTech) і штучного інтелекту. Це забезпечує значне удосконалення інтернет-можливостей офшорного банківництва, динамічне впровадження інноваційних стартапів у банківську сферу, підвищення ефективності і зниження трансакційних витрат офшорних банківських сервісів, а також оперативну монетизацію технологій віртуальної і доповненої реальності. Достатньо сказати, що нині 1 з кожних 3 мобільних додатків використовується споживачами для управління власними фінансовими коштами [5].

Так, за прогнозними оцінками Bank of England, вже до 2023 р. фінтек-сектор спричинить загальне скорочення прибутків британських банків на 1,1 млрд фунтів стерлінгів з причин значного зниження вартості їх платіжних послуг і доходів від овердрафту [10, с. 21]. Тож якщо ще кілька десятиліть назад власники офшорних банківських рахунків після їх відкриття у більшості випадків здійснювали мінімальні операції зі своїми активами, то нині для них простіше ніж будь-коли контролювати свої кошти, відкривати депозитні вклади, проводити грошові перекази, моніторити баланси офшорних рахунків способом використання банківських технологій онлайн-сервісів [7].

Наступною тенденцією, яка підтверджує глобальний характер сучасного офшорного банкінгу, є активне проникнення у даний сектор технологій електронної комерції. 3 урахуванням загальносвітового тренду щодо стрімкого зростання частки електронної комерції у глобальних роздрібних продажах (на рівні 14\% вартісного обсягу і $25 \%$ світового населення на даний час [7]), це суттєво підвищить у майбутньому 
популярність офшорних банків в якості важливих інститутів обслуговування глобальних роздрібних продажів, не потребуючи при цьому прив'язки до конкретного місця. Вже сьогодні, дедалі більша кількість компаній і підприємницьких структур, що працюють по усьому світу, орієнтуються на переведення свого бізнесу на сервісне обслуговування 3 боку офшорних банків, проведення офшорних банківських операцій та широке застосування офшорних фінансових інструментів [5]. I це цілком закономірно, оскільки за наявності в економічних агентів офшорних банківських компаній й офшорних банківських рахунків вони отримують безперешкодні можливості оплати картками товарів і послуг, придбаних у будь-якій точці планети способом використання платіжних систем Dal Pay, Pay Pal та ін. При цьому офшорними банками забезпечується повна конфіденційність і максимальний фінансовий захист здійснених трансакцій у сфері електронної комерції.

Ще однією новітньою тенденцією розвитку банківського офшорингу, яка свідчить про іії глобальний рівень, $є$ активне його переведення на технології блокчейну. Тренд до стрімкої інтенсифікації даного процесу в останне десятиліття набув, на нашу думку, тривалого й усталеного характеру та виявляється на даний час у динамічному поширенні в офшорному банкінгу операцій з криптовалютами - біткоіном, альткоіном, ефіріумом, райплом, лайткоіном тощо. Хоч дані валюти дуже часто демонструють значну курсову волатильність, не забезпечені жодними активами, не гарантують повної анонімності здійснюваних операцій та характеризуються доволі високими ризиками грошових втрат для клієнтів, з року в рік зростають вартісні обсяги номінованих у них розрахункових, обмінних і майнингових операцій, що здійснюються в офшорних юрисдикціях від імені офшорних компаній.

Більше того, офшорні юрисдикції жодним чином не обмежують та не ліцензують операції з криптовалютами, підтримують реалізацію різного роду блокчейн-стартапів та організацію бірж з торгівлі цифровими валютами. Відтак - це справлятиме, на нашу думку, вагомий вплив на механізми функціонування офшорного банківництва упродовж наступного десятиліття насамперед в частині глибокої конвергенції криптовалютних активів й офшорних банківських продуктів. В якості прикладу наведемо, зокрема, Панаму-сіті, де нині базується стартап Coinapult, чиї платформи дають змогу клієнтам офшорних банків купувати біткоіни за фіатную валюту. Своєю чергою, на Сейшельських островах розташовані сервери обміну цифрових валют ВТС, а Британські Віргінські острови посідають друге місце після Сполучених Штатів Америки за кількістю зареєстрованих стартапів у сфері реалізації операцій з криптовалютами [16].

Характеризуючи глобальні тенденції розвитку офшорного банківництва, не можемо не відзначити усезростаючий його вплив на зниження податкових ставок на доходи фізичних осіб та прибутки корпоративного сектору у багатьох країнах світу. Це стає причиною значного зниження рівня маржинального прибутку банків, а відтак актуалізує проблему щодо пошуку ними найбільш привабливих глобальних точок ведення банківської діяльності. Наприклад, Австралія характеризується нині дуже високими ставка прибуткового оподаткування банків, що суттєво знижує ії конкурентні позиції як локалу офшорного банківництва, порівняно 3 державами паназійського регіону (Тайваню, Сінгапуру, Китаю тощо). Водночас на тлі зменшення середньосвітової ставки прибуткового оподаткування та загострення міждержавної податкової конкуренції, на нашу думку, суттєво розширяться географічні ареали відкриття офшорних банків (у Центральній і Східній Європі, Південно-Східній Азії, Близькому і Середньому Сході, Північній Африці), зорієнтованих на задоволення зростаючих потреб глобального бізнесу і фізичних осіб в офшорному банківському обслуговуванні.

Значне загострення конкурентної боротьби на глобальному ринку банківських послуг породжує ще один важливий тренд розвитку сектору офшорного банківництва - 
це посилення клієнт-орієнтованості і персоніфікованості офшорних банківських операцій. Підтвердженням цього $\epsilon$, зокрема, той факт, що нині менше половини здійснюваних офшорними банками трансакцій припадає на взаємні банківські операції, тоді як загалом за системою міжнародних банків даний показник стабільно перевищує 65\%. Більше того, на Бермудських островах, у Вест-Індії та острові Джерсі офшорний міжбанківський ринок в рази поступається операціям офшорних банків зі своїми корпоративними і роздрібними контрагентами [15, с. 104].

Таким чином, клієнтам офшорних банків надається на сьогодні широкий спектр послуг, що виходить далеко за рамки власне банківського обслуговування, й охоплює також консалтингові сервіси 3 питань податкового законодавства, оптимізації податкових витрат, заснування офшорного бізнесу тощо. Водночас, для бізнесменів $\mathrm{i}$ фізичних осіб, які відчувають гострий брак інвестиційного капіталу у себе на батьківщині, офшорні банки пропонують широкий вибір джерел фінансування, а відтак - забезпечують ефективну диверсифікацію інвестиційних портфелів своїх клієнтів, надійний захист їх активів й виведення останніх з країн реєстрації.

Подібний «симбіоз» власне банківського й інвестиційного обслуговування клієнтів породжує ще одну важливу сучасну тенденцію розвитку глобального банкінгу. Йдеться про глибоку конвергенцію діяльності офшорних банків й міжнародних інвестиційних компаній зі створенням і динамічним розвитком високоспеціалізованих професійних команд. Спеціалізуючись у сфері управління офшорними інвестиціями і банківськими операціями, подібні команди здійснюють також контроль за дотриманням діючих у цій царині нормативних вимог і положень з метою диверсифікації послуг для своїх клієнтів щодо структурування фінансових ресурсів. Крім цього, на найближчу перспективу можна очікувати дедалі більше «дрейфування» зазначених банківсько-інвестиційних команд у бік офшорного обслуговування захисту активів економічних агентів різної національної належності, структурування і реструктуризації їх фінансів і планування нерухомості, розроблення для клієнтів податкових й інвестиційних стратегій, консалтингового обслуговування їх виходу на міжнародні фондові майданчики.

Ще одна фундаментальна тенденція може найближчими роками суттєво вплинути на найбільших клієнтів глобального офшорного банкінгу. Це - активізація злиттів трастових офшорних компаній та їх поглинання з боку юридичних, бухгалтерських й аудиторських компаній. У сукупності зазначені процеси інтегрують новостворені компанії до системи регуляторного арбітражу офшорних операцій та спричинять якісно нові трансформаційні зміни в офшорному банківському бізнесі [1], пов'язані насамперед 3 їх територіальною «дифузією» за багатьма географічними регіонами.

Висновки. Завершуючи, наголосимо, що умови глобального економічного розвитку суттєво активізували діяльність офшорних банків та спричинили глибоку якісну диверсифікацію структури їх транскордонних операцій. На найближчу перспективу сектор глобального офшорного банківництва зазнає суттєвих трансформаційних змін, пов'язаних з його системною технологізацією й динамічним поширенням фінтеху і штучного інтелекту, активним проникненням у даний сектор блокчейн-технологій й інструментарію електронної комерції, зростанням впливу офшорних банків на зниження податкових ставок на доходи фізичних осіб та прибутки корпоративного сектору, посиленням клієнт-орієнтованості і персоніфікованості офшорних банківських операцій, глибокою конвергенцією діяльності офшорних банків й міжнародних інвестиційних компаній, створенням i динамічним розвитком високоспеціалізованих професійних команд. У сукупності зазначені процеси не тільки суттєво посилять вплив офшорного банківництва на структурну динаміку світогосподарського розвитку, але й модернізують традиційні схеми використання офшорних фінансових мереж 3 метою максимального задоволення потреб у 
банківському і квазібанківському обслуговуванні найбільш впливових економічних гравців з числа оншорних держав.

Список бібліографічного опису:

1. 5 Offshore Banking Trends for 2019. URL: https://medium.com/@icoservices/5-offshore-banking-trends-for-20191e882a7298b6

2. Estimating International Tax Evasion by Individuals. Taxation Papers. Working Paper No. 76-2019. European Commission. Luxembourg: Publications Office of the European Union, 2019.

3. Garcia-Bernando J., Fichtner J., Takes F. W., Heemskerk E. Uncovering Offshore Financial Centers: Conduits and Sinks in the Global Corporate Ownership Network. Scientific Report. $2017 . \quad$ Volume 7. URL: https://www.nature.com/articles/s41598-017-06322-9

4. International Financial Centers / Lane P. R., Milesi-Ferretti G. M. IMF Working Paper. URL: https://www.imf.org/external/pubs/ft/wp/2010/wp1038.pdf.

5. Offshore Banking Trends of 2019. URL: https://alpenrosewealth.com/insights/offshore-banking-trends-of-2019/

6. Summary of locational statistics, by currency, instrument and residence and sector of counterparty. Outstanding at endMarch 2020, in billions of US dollars. BIS. URL: http://stats.bis.org/statx/srs/table/a1?m=S\&p=20201\&c=

7. Wewege L. Seven Trends in Offshore Banking. IFC, 18.11.2019. URL: https://www.ifcreview.com/articles/2019/november/seven-trends-in-offshore-banking/

8. Березной А. Транснациональный бизнес в эпоху глобальной цифровой революции. Мировая экономика и международные отношения. 2018. Том 62. №9. С. 5-17.

9. Власюк О. С. Актуальні проблеми фінансової безпеки України в умовах посткризової трансформації : монографія. К.: НІСД, 2014.

10. Желюк Т. Л. Розвиток фінансового ринку в контексті забезпечення національної безпеки. Інноваційна економіка. 2019. №3-4. C. 18-23.

11. Ишханов А. В. Сравнительный анализ оффшорных банковских юрисдикций. Финансы и кредит. 2001. №15 (87). C. $74-80$

12. Красавин И. В. Офшоры как негосударственные акторы мировой политики. Вестник МГИМО Университета. 2013. №2 (29). С. 62-67.

13. Макарова И. К. Офшоринг как инновационный способ ведения бизнеса в условиях глобализации и регионализации экономик. Международное сотрудничество евразийских государств: политика, экономика, право. 2017. №3. С. 77-86. 14. Матусевич А. П. Офшорные зоны: история, тенденции развития, влияние на российскую экономику. Вестник Международного института экономики и права. 2013. № 1 (10). С. 37-48.

15. Международный офшорный бизнес. Учебное пособие для бакалавриата и магистратуры / Б. Логинов, Е. Смирнов, А. Михайлин. Москва, 2019.

16. Операции с криптовалютой в оффшорах. Niemands Legal, 24.08.2017. URL: https://niemands.ru/presscentr/articles/operacii-s-kriptovalyutoj-v-offshorah

17. Пузакова Е. П., Шепель Т. С. Содержательная структура процесса офшоризации мировой экономики с позиций уровневого подхода. Национальные интересы: приоритеты и безопасность. 2015. №10 (295). С. 57-64.

18. Смирнов Е. Н. Офшорные схемы в современном международном движении капитала: особенности и механизмы противодействия. Вестник Евразийской науки. 2018. Том 10. URL: https://esj.today/PDF/66ECVN518.pdf

19. Терехова В. В. Правовое регулирование деятельности офшорных банков в некоторых юрисдикциях. Теория и практика общественного развития. 2019. Выпуск $10 . \quad$ URL: http://teoriapractica.ru/rus/files/arhiv_zhurnala/2019/10/law/terekhova.pdf

20. Ужгинцев А. В. Офшорные компании в современной экономике. Российский внешнеэкономический вестник. 2012. №5. C. 94-103.

21. Ярошевич В., Сарган А. Оффшорный сегмент мировой экономики: эволюция и тенденции развития. Банкаўскі веснік, Сакавік 2013. С. 33-39.

\section{References}

1. Offshore Banking Trends for 2019. URL: https://medium.com/@icoservices/5-offshore-banking-trends-for-20191e882a7298b6

2.Estimating International Tax Evasion by Individuals. Taxation Papers. Working Paper No. 76-2019. European Commission. Luxembourg: Publications Office of the European Union, 2019.

3.Garcia-Bernando J., Fichtner J., Takes F. W., Heemskerk E. Uncovering Offshore Financial Centers: Conduits and Sinks in the Global Corporate Ownership Network. Scientific Report. 2017. Volume 7. URL: https://www.nature.com/articles/s41598017-06322-9

4.International Financial Centers / Lane P. R., Milesi-Ferretti G. M. IMF Working Paper. URL: https://www.imf.org/external/pubs/ft/wp/2010/wp1038.pdf.

5.Offshore Banking Trends of 2019. URL: https://alpenrosewealth.com/insights/offshore-banking-trends-of-2019/

6.Summary of locational statistics, by currency, instrument and residence and sector of counterparty. Outstanding at end-March 2020, in billions of US dollars. BIS. URL: http://stats.bis.org/statx/srs/table/a1?m=S\&p=20201\&c=

7.Wewege L. Seven Trends in Offshore Banking. IFC, 18.11.2019. URL: https://www.ifcreview.com/articles/2019/november/seven-trends-in-offshore-banking/

8. Bereznoy A. Transnatsionalnyy biznes v epokhu globalnoy tsifrovoy revolyutsii. Mirovaya ekonomika i mezhdunarodnyye otnosheniya. 2018. Tom 62. №9. S. 5-17.

9.Vlasyuk O. S. Aktual`ni problemy` finansovoyi bezpeky`Ukrayiny`v umovax postkry`zovoyi transformaciyi: monografiya. K.: NISD, 2014. 
10. Zhelyuk T. L. Rozvy`tok finansovogo ry`nku v konteksti zabezpechennya nacional`noyi bezpeky`. Innovacijna ekonomika. 2019. \#3-4. S. 18-23.

11. Ishkhanov A. V. Sravnitelnyy analiz offshornykh bankovskikh yurisdiktsiy. Finansy i kredit. 2001. №15 (87). S. 74-80.

12. Krasavin I. V. Ofshory kak negosudarstvennyye aktory mirovoy politiki. Vestnik MGIMO Universiteta. 2013. №2 (29). S. 62-67.

13. Makarova I. K. Ofshoring kak innovatsionnyy sposob vedeniya biznesa v usloviyakh globalizatsii i regionalizatsii ekonomik. Mezhdunarodnoye sotrudnichestvo evraziyskikh gosudarstv: politika. ekonomika. pravo. 2017. №3. S. 77-86.

14. Matusevich A. P. Ofshornyye zony: istoriya. tendentsii razvitiya. vliyaniye na rossiyskuyu ekonomiku. Vestnik Mezhdunarodnogo instituta ekonomiki i prava. 2013. №1 (10). S. 37-48.

15. Mezhdunarodnyy ofshornyy biznes. Uchebnoye posobiye dlya bakalavriata i magistratury / B. Loginov. E. Smirnov. A. Mikhaylin. Moskva. 2019.

16. Operatsii s kriptovalyutoy $\mathrm{v}$ offshorakh. Niemands Legal. 24.08.2017. URL: https://niemands.ru/presscentr/articles/operacii-s-kriptovalyutoj-v-offshorah

17. Puzakova E. P., Shepel T. S. Soderzhatelnaya struktura protsessa ofshorizatsii mirovoy ekonomiki s pozitsiy urovnevogo podkhoda. Natsionalnyye interesy: prioritety i bezopasnost. 2015. №10 (295). S. 57-64.

18. Smirnov E. N. Ofshornyye skhemy v sovremennom mezhdunarodnom dvizhenii kapitala: osobennosti i mekhanizmy protivodeystviya. Vestnik Evraziyskoy nauki. 2018. Tom 10. URL: https://esj.today/PDF/66ECVN518.pdf

19. Terekhova V. V. Pravovoye regulirovaniye deyatelnosti ofshornykh bankov v nekotorykh yurisdiktsiyakh. Teoriya i $\begin{array}{lllllll}\text { praktika obshchestvennogo } & \text { razvitiya. } & 2019 . & \text { Vypusk } & 10 . & \text { URL: }\end{array}$ practica.ru/rus/files/arhiv_zhurnala/2019/10/law/terekhova.pdf

20. Uzhgintsev A. V. Ofshornyye kompanii v sovremennoy ekonomike. Rossiyskiy vneshneekonomicheskiy vestnik. 2012. №5. S. 94-103.

21. Yaroshevich V., Sargan A. Offshornyy segment mirovoy ekonomiki: evolyutsiya i tendentsii razvitiya. Bankay̆ski vesnik. Sakavik 2013. S. 33-39.

Дата подання публікації 17.09.2020 p. 